\title{
SMALLPOX PLAGUE IN COLONIAL BRAZIL Historical tragedy or genocide? ${ }^{1}$
}

\author{
Ronaldo Vainfas \\ PhD by USP \\ Professor of Post-Graduate Studies in History at \\ Universidade do Estado do Rio de Janeiro (UERJ) and at Universidade Federal do Rio Grande \\ do Norte (UFRN) \\ ORCID: https://orcid.org/0000-0003-0069-0374 \\ Email: rvainfas@terra.com.br
}

Received on: July 13, 2020

Approved on: November 20, 2020

\begin{abstract}
:
This article studies the impact the $16^{\text {th }}$ century smallpox pandemic had on the indigenous population of the Brazilian coast. It offers a comparison between the spread of smallpox in colonial America and the European Black Plague in the Late Middle Ages. It discusses the smallpox pandemic in the context of Iberian colonization, especially the Portuguese one. It analyzes the hypothesis of the African origin of the strain of smallpox spread in Brazil. It also examines quantitative evidence on native mortality, relating it to the procedures adopted in the Jesuit villages. Finally, it evaluates the relevance of concepts such as Genocide or Necropolitics for the studies on the smallpox pandemic in the 16th century.
\end{abstract}

Keywords: Smallpox, Native Brazilians, Genocide.

\section{Resumo:}

O artigo é dedicado ao estudo do impacto da pandemia de varíola na população indígena do litoral brasileiro durante o século XVI. Ele oferece uma comparação entre a disseminação da varíola na América colonial e a da Peste Negra europeia no final da Idade Média. Discute a pandemia de varíola no contexto da colonização ibérica, principalmente a portuguesa. Analisa a hipótese da origem africana da varíola disseminada no Brasil. Também examina as evidências quantitativas sobre a mortalidade indígena, relacionando-a aos procedimentos adotados nas aldeias jesuítas. Por fim, avalia a relevância de conceitos como genocídio ou necropolítica para os estudos sobre a pandemia de varíola no século XVI.

Palavras-chave: Varíola, Indígenas, Genocídio. 


\section{Introduction}

Jacques Le Goff organized, in 1985, a book - translated to Portuguese and entitled As doenças têm história - about the history of diseases, based in a dossier published in the $74^{\text {th }}$ edition of the journal L'Histoire, Les Maladies ont une histoire. A small, 134-page book, with short articles on several diseases, on the social impact of epidemics, on adopted therapeutics, on vaccines against bacteria and viruses, on collective feelings; a work using the view of long duration, that is characteristic of the history of mentalities. At that time, mentalities, as concept, was declining, criticized on all sides: some rejected its interclass option and its abandonment of total history; others, conversely, considered it an inconsistent concept anthropologically, since it considered alterity in time using concepts of the $20^{\text {th }}$ century, inherited from rational scientism. British scholar Stuart Clark published an iconic article against French history of mentalities from an anthropological point of view (CLARK,1983: p.65).

In any event, in 1985, Le Goff still considered valid the concept of mentalities. In the presentation of the book, translated by the Portuguese publisher Terramar in that same year, he wrote "that disease belongs not only to the History of scientific and technological progress, but also to the deep History of knowledge and practices connected to social structures, to representations, to mentalities" (LE GOFF, 1991: p.8). He intended, in a way, to disconnect the history of diseases from the conventional History of Science; not to deny it, of course, but to think about it in the sociocultural field.

As doenças têm história includes remarkable articles on plagues in Western history, like the bubonic plague, syphilis, smallpox; on epidemies or pandemics that afflicted populations and provoked at times mystical flares, at times therapeutical efforts which gave great contributions to western medicine.

Nowadays, it is a consolidated field of research both in Cultural History - its natural vocation, due to its proximity with Anthropology — and in the History of Science, that has incorporated sociocultural perspective in many works. At the time this book was released, this was all very new. As we reach the third decade of the $21 \mathrm{st}$ century, this theme is very relevant, regardless of conceptual debates. The year 2020 
saw the beginning of one of the biggest pandemics in history, caused by a virus as yet unknown. It is responsible for millions of infected and hundreds of thousands of deaths in a multicontinental scale. A worldwide tragedy, a calamity which historians can help to scientifically — or, at least humanely — analyze.

\section{The Black Plague, white people pandemics}

In the work organized by Le Goff, this theme is addressed by Robert Delort: May the Plague be the Rat (Que a peste seja o rato). This is the title of the article on the Black Plague that scourged Europe during the 14th century, which returned on a smaller scale in the 15 th century, and also hit - one must remember - several regions in Asia at the same time.

The variant of this pandemic to hit Europe was the Bubonic Plague, which Delort classified as the most devastating pandemic in human history, centered in vast Eurasia, with lethality rate running into millions. According to Delort, the height of the plague in Europe occurred between 1347 and 1351, When circa one third of the population lost its life by asphyxiation, suffering from sores spread on the body. Some authors mention numbers such as 40 percent or higher of fatal victims of the black plague in Europe. What do these numbers and percentages mean in terms of human lives?

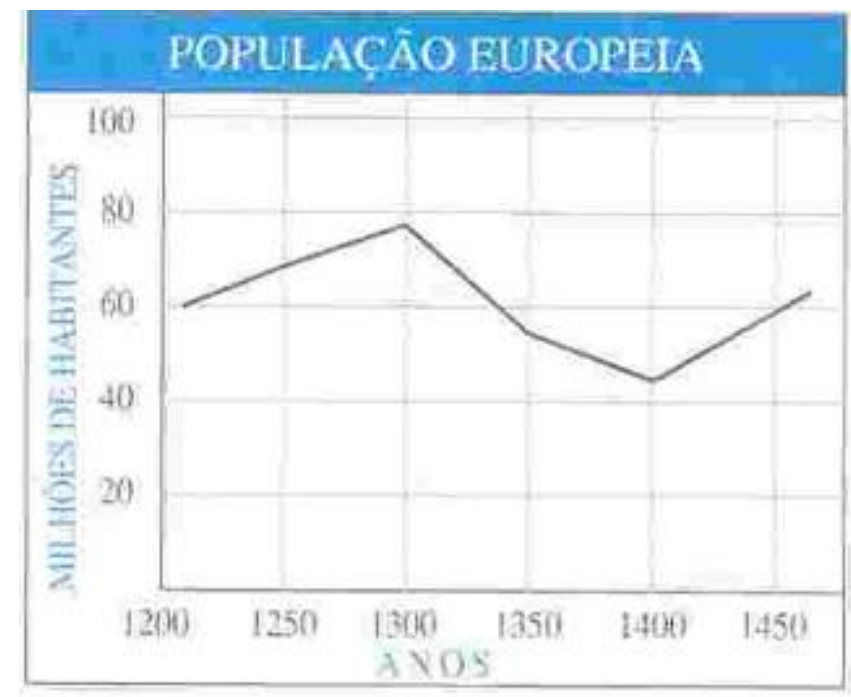

IMAGE 1 - http://historia8eb23dduarte.blogspot.com/2007/09/populao-europeia.html 
This is something we can only estimate, due to the absence of censuses and of sources with statistic value. Delort's estimates are reasonable, although inexact - they could be nothing else. European population, between 1300 and 1350, varied between 60 and almost 80 million people - the bigger number including Hungary, Poland, and the European part of the Byzantine Empire; the smaller number referring only to Western Europe. Delort places the demographic tragedy of Western Europe at the end of the 1340 s and the beginning of the 1350s. But this catastrophe was longer, running into the $1400 \mathrm{~s}$, when the population of 60 million decreased to 40 million. The estimates confirm that one third of the population of Western Europe died of the plague in the second half of the $14^{\text {th }}$ century, which is equivalent to 20 million dead.

If the Black Plague was actually the most devastating pandemic in universal history, as Delort claims, we shall see along this article; but it is common knowledge that the suffering caused by this plague was terrifying. It is a bacterial disease, caused by a rod-shaped bacillus. The bacillus is inoculated by flea bites, from fleas carried by contaminated rodents. When they bite humans, these fleas transmit Yersinia pestis, the scientific name for this bacterium, which penetrates the skin and travels to the lymphatic vessels, defeats the lymphocytes that defend the body and, when it reaches the lungs, kills the host in around ten days.

In his article, Delort carefully examines the world of rodents, in special the rats contaminated by the bubonic bacteria, whose vector is the flea - we can say that the team rat-flea had an arrangement in this plague. The rats, however, also died, and the abundance of dead rats in medieval cities was an indication that the plague had arrived. Delort points out the black rat, called Rattus rattus, as the greatest vector of the plague among the rodents (DELORT, 1985: p.111). They usually travel in groups, one male to several females, and prefer to build their nests in attics, ceilings, wall cracks, warehouses, ship's holds, and harbor areas. It is a predominantly urban rat, differing from the brown rats, which are mainly rural. Brown rats, however, also transmitted the European plague of the 14th century through their fleas.

The characteristics of the black rat match what we know about the Black Plague. The plague attacked mainly cities and villages, places where there existed agglomeration of people, and arrived through the Mediterranean Sea, the sea route that brought to Europe spices from India and China, coming from the Black or Red Seas. 
Venice, on the Adriatic Sea, and Genoa, on the Tyrrhenian Sea, were the most relevant Italian cities to the import and distribution of this merchandise in Europe.

The Black Plague route most accepted by historians who study the Middle Ages point to Sicily, in the South of Italy as the entrance point, estimating October 1347 as the starting point of the plague. Brought by twelve Genovese galleys, it soon spread through the island and reached Genoa itself, Pisa and then Venice, in 1348. The Italic Peninsula, in the 14th century, was the European epicenter of the Black Plague, and likewise of the COVID-19 pandemic in 2020. In medieval times the epidemic spread to France, through Marseille, following the internal terrestrial or maritime commerce routes of the time. Ports and country fairs, such as the one in Champagne, in France, were radiating centers of the great plague.

According to Jean-Noël Biraben, specialist in the history of the Black Plague in France and in the Mediterranean, the plague - in short and medium term - caused violent outbreaks in the cities every 8,10 , or 15 years, causing the loss of up to 40 percent of their population, and persisting afterwards in an almost endemic state, "roaming capriciously from a street or a district to another, seasonally, during one, two, and up to five years in a row" (Apud DELUMEAU, 1989: p.108).

This is a good description of the routine of the Black Plague, which is responsible for the emergence of Ars Moriendi, a group of illustrated texts of Latin literature produced in the first half of the 15 th century, dedicated to the counselling of individuals in the art of "dying well", to achieve spiritual salvation, what was to all the most important consideration. Since the $14^{\text {th }}$ century, however, we see a dissemination of a "culture of death", either literary or iconographic, produced at times by the popular classes, at other times by the cultured classes. All these shared the "culture of death", in order to tame it (ARIÈS, 1977: p.17-29) or as an expression of an unbearable collective fear. 


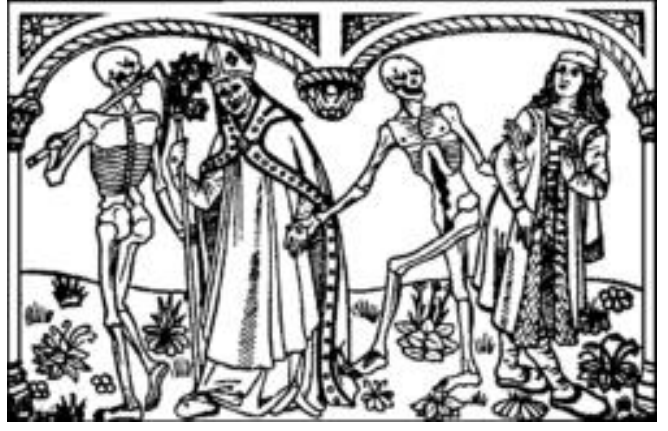

IMAGE 2 - The Dance of Death, woodcut by Michael Wolgemut in The Nuremberg Chronicle, 1493.

Public dominion. Available at:

https://pt.wikipedia.org/wiki/Danç_macabra\#/media/Ficheiro:Danse_macabre_by_Michael_Wolg emut.png

\section{The smallpox pandemic in America}

The demographic catastrophe that hit the native populations of the Americas offers us stratospheric numbers. In Aztec Mexico, the best-known case, a population estimated in 25 million people in 1519, when Cortez arrived there, barely passed one million in 1605 (SANCHEZ-ALBORNOZ, 1973: p.72). That would be enough to counter Delort's claim that the Black Plague was "the most devastating pandemic in human history", at least on the count of deaths. In the Incan Empire, whose data is more imprecise, at least 15 million natives died of smallpox in the 15th century, including Emperor Huaina Cápac, before the conquest led by Francisco Pizarro in the 1530s (WACHTEL, 197: p.59-61).

Death spread everywhere. In the Antilles, first scenario of contact between Natives and Spaniards, certain islands lost all their native population between the end of the $15^{\text {th }}$ century and the first years of the $16^{\text {th }}$. We could cite multiple examples, remembering that 90 percent of the native population was concentrated in slightly over 5 percent of the surface of the continent, especially in Mesoamerica and Central Andes. The mortality rate of the native population in these regions could have reached and even surpassed 50 million people.

The high mortality rates were caused by a multi-agent epidemic, with simple influenzas that evolved quickly into pleurisies and pneumonias, "three-day fevers", as 
the Portuguese called malaria (in some regions, it became endemic) and other diseases. There is, however, a consensus that smallpox was the biggest villain to the native populations of the continent in the 1500 s.

In the book As doenças têm história, Pierre Darmon signed the article "The Crusade Against Smallpox" ("A cruzada antivariólica"), focusing, however, in the sanitary actions of the 19th and 20th centuries, escaping the scope of the present article. But it is worth saying, however, that smallpox is a viral disease, not bacterial like the bubonic plague. It is transmitted through the air and physical contact; it reaches the lungs and causes blisters in the skin of the infected person.

There is mention, in Thucydides, of a plague in Athens, in the 5th century BC, which some presume to be smallpox, that was responsible, along with other factors, for the decline of the Greek Polis as a Mediterranean power of the time. Hippocrates, however, does not describe the disease, unknown before that time, and it is not determined if it truly is an epidemic of smallpox.

Except for this debatable episode, smallpox is said to have arrived in Europe through the Iberic Peninsula, carried by the Umayyads, which conquered it in the $8^{\text {th }}$ century, and it reappeared in force after the $9^{\text {th }}$ century, during the Reconquista and the increase of commerce between Europe and the Near East. Many presume that the origin of smallpox is Asian or African, but these are improbable speculations, especially when coming from Western historians. In the history of great epidemics, it is common to attribute the origins of the tragedy to external groups, and in Europe this is almost a consensus. In the African case, as we shall see, mentions of smallpox epidemics only appear in the $17^{\text {th }}$ and $18^{\text {th }}$ centuries, and the African populations were victims, not vectors, of these plagues.

In Europe, smallpox became endemic along the Modern Era, but with relatively low mortality rate. It is estimated that 400 thousand people died of smallpox in the continent during the 18th century, what is equivalent - considering a population of 85 million people in Western Europe - to $0.5 \%$ of annual mortality rate for this disease.

It is also known that the Europeans practiced a more or less efficient therapy against smallpox, imported from China - what seems to confirm that the Middle Kingdom was at some point the epicenter of the pandemic of smallpox, between the 
Western Middle Ages and Modern Era. The treatment was to scrape the sores of the infected patient, turn that into a powder, and make the individual inhale that powder. We could say it was an empiric treatment which certainly inspired the experiments of the English physician Edward Jenner, which are considered pioneer in the history of the smallpox vaccine (see note 3 ).

\section{4 - The bexigas in Brazil}

In the Brazilian 1500s, smallpox was relentless, killing thousands of natives in the 16th century. It became known as peste das bexigas (plague of blisters), because of the stench exhaled by the skin blisters in terminal patients. In Dicionário da Lingua Portuguesa by Antonio Moraes Silva, a dictionary dating from 1789, there are two meanings offered for the word bexiga. The first, valid to this day, defines bexiga as bladder: "a membranous sac that is the receptacle for urine"; the second meaning says: "blister (bubble or bladder) that forms on the skin, with acrid and corrosive humors, generally used in plural form" (SILVA, 1813, vol. I: p.280). The second meaning is the one of interest to us.

The epicenter of this plague of blisters, on the Brazilian coast, was Bahia, after the decade 1560. Alexander Marchant, in his classic book Do escambo à escravidão (From Barter to Slavery), mentions two different outbreaks of smallpox, between 1562 and 1563, but, in reality, these were two peaks of the same epidemic (MARCHANT, 1980: p.102). The first peak occurred in the outskirts of Bahia, in 1562, plaguing villages near Salvador or in Recôncavo Baiano, and lasting three to four months. At least thirty thousand natives died during this outbreak. The second peak started in the city of Ilheus, also in 1562, lasted about a year and hit Bahia in 1563. There is less data on this second peak, but a Jesuit priest claimed that, out of every twenty infected patients, twelve died. In the village of Nossa Senhora d'Assunção, circa 25\% died out of a population of four thousand natives.

The plague of blisters worsened and gave continuity to several epidemics that had appeared since the 1550s, the already mentioned pleurisies, pneumonias, and "three-day fevers", which in some regions became endemic. There is news, in Jesuit correspondence, of a strong influenza that, in 1552, afflicted the native population of 
Pernambuco, a region which spearheaded the budding sugarcane economy of the coast, based on native slavery. There is, however, documentation on a non-specific disease that spread throughout Rio de Janeiro, in 1558. Another epidemic, of unknown variety, attacked the Tupiniquim population of São Paulo in 1560, few years after the foundation of the Jesuits in Piratininga. There are records of epidemics prior to the smallpox catastrophe, even before the natives were led down to the coast to be catechized or enslaved. In Rio de Janeiro, around the year 1558, a pleurisy hit the Tupinambá population, spreading all the way to Espirito Santo. The estimates say that circa onesixth of the natives died of this infection. In this case, the epidemic occurred in a region not yet occupied by the Portuguese; the pleurisy that spread in Guanabara was possibly brought by the French, who founded France Antarctique in 1555. Even at the time of redwood bartering between Natives and Portuguese or French, fatal illnesses were transmitted to the native groups.

There was no epidemic, however, that came close to the smallpox outbreaks occurred in the Brazilian coast after 1562. These outbreaks lasted until the 1580s, in successive waves, with documents that attest that the native population Bahia fell from circa forty thousand, in 1564 , to ten thousand, in 1585 . A lethality rate of $75 \%$ in the area, along twenty years, a rate superior to the lethality rate of the Black Plague in Europe during the $14^{\text {th }}$ century.

There is controversy concerning the origin of the smallpox in the Brazilian coast in the $16^{\text {th }}$ century. The so-called traditional opinion blames the plagues of 1562 to the arrival of a Portuguese boat with infected people. But were the vectors of the smallpox epidemic Portuguese? It is hard to say with any certainty, and Marchant observed, correctly, that the Jesuit accounts of the blisters do not mention Portuguese victims (MARCHANT, 1989: p.103). Possibly, the Portuguese persons disembarking in 1562 were already immune, if we trust the hypothesis offered by Joseph Miller and Dauril Alden, in an article published in 1988, with a conclusive title: Unwanted cargoes: the origins and dissemination of Smallpox via slave trade from Africa to Brazil. ${ }^{2}$

In this article, published in a book about slave traffic and interchanges between Africa and America, Aldrin and Miller associate the entrance of the virus in the Brazilian coast with the increase of Atlantic slave traffic, when larger numbers of enslaved Africans started to reach the coast. They mention, in support to this hypothesis, 
the absence of documentation of smallpox occurrences in the first decades of contact, the redwood time - even if, as I mentioned before, there were other kinds of epidemics along the coast, and even before the time of the sugarcane solution for the colonization of Brazil.

It is a plausible hypothesis, even if it is doubtful, especially because smallpox only spread among the natives of the coast in the $1560 \mathrm{~s}$, the period when we see the structuring of the sugarcane economy and of the Jesuit catechesis - not before, when the contact between native groups and Europeans was occasional.

To counter this hypothesis, and the Western tradition of attributing the origin of epidemics to other peoples or continents, I mention the work of the great Africanist Alberto da Costa e Silva. In his book A manilha e o libambo (The Shackle and the Chain), the author mentions smallpox in three situations: talking about an epidemic that struck the old Kingdom of Monomotapa (current Mozambique), in the Middle of the 17th century; a comment on "new forms of smallpox" that, along with other diseases, afflicted the populations of Western and Central-Western Africa during the $17^{\text {th }}$ century; mention of a smallpox epidemic in the extreme South of Africa, in 1715. All of it "brought from Europe, from Asia, and from the Americas" (SILVA, 2002: p.668, 774 e 874).

Which cultural group, which continent took smallpox to the Brazilian coast in the 1500s? The traditional hypothesis of the Lisbon ship of 1562 seems to me more creditable. However, the aim here is not to identify the agents responsible for the dissemination of smallpox among the natives - either Portuguese or Africans - but to consider that, in a wide sense, smallpox was inoculated "in the body of Brazil" - as Baeta Neves (NEVES, 1978: p.134) would say - through the Portuguese-African settlements and the sugarcane exploitation, some masters, some slaves, but mainly through the Jesuit catechesis. In Modern Age, the triangle Portugal-Africa-Brazil founder of an Atlantic cultural identity, as many claimed, from Gilberto Freyre, in his Casa Grande \& Senzala (FREYRE, 1973) to current historiography (CALAINHO, 2008) - was also decisive for the large-scale decimation of the native population in the Brazilian coast.

The dissemination of smallpox among native groups also relates to a classic debate in Brazilian historiography. Fernando Novais, a leading name of Brazilian 
historiography since the 1960s, associates the expansion of African slavery, in place of native slavery, to commercial interests of the Atlantic slave traffic (NOVAIS, 1979: p.98). Undeniable interests, since African slavers in the Atlantic had much greater financial gain than the slavers of Native Brazilians in the hinterlands of Brazil. In opposition to that, Ciro Cardoso claimed, since the 1970s, that the substitution of the Native slave for the African slave in the Brazilian coast, as in other parts of the continent, was due to the depletion of the Native Brazilian population as workforce for colonial plantations (CARDOSO, 1975: p.65).

The spreading of smallpox after the 1560s helps to sustain Cardoso's position, especially because African slave traffic started to grow exactly at that time. However, on the side, there still remains an interesting question, almost a charade: was smallpox brought by enslaved Africans, and - destroying the native population of the coast increased African slavery as a substitute to indigenous slavery? It is impossible to answer with precision, but such relations demonstrate the complexity of historical processes and the inconsistency of single cause explanations.

What is certain is that smallpox spread along all the coast, among Native Brazilians, until the end of the $16^{\text {th }}$ century. It did not exterminate the Native Brazilian population of the coast, as some claim, but reduced it drastically, turning the region into a land of endless evils (MAESTRI, 1995). The plague did cause a demographic catastrophe among the natives that, in a certain sense, is comparable to what happened in Central Mexico and Central Andes during the $16^{\text {th }}$ century.

Smallpox spread, from Bahia and Ilheus, to the Captaincies to the north, reaching Pernambuco, and to the Captaincies to the south, towards Rio de Janeiro, to Espirito Santo and to the high plain of Piratininga - killing Chief Tibiriçá of the Tupiniquim, ally of João Ramalho, who the Jesuits considered a "petra scandali of Vincentian colonization", due to the fact that he had, on account of his warrior's prowess, several native wives. João Ramalho died of old age, over eighty years old, as a city councilor of the Chamber of São Paulo, without ever being hit by any epidemics.

Jesuit correspondence constitutes, without a doubt, a great source for the description of the routine of the smallpox plague that afflicted the population of the Brazilian coast. In a letter to the Provincial of the Company in Portugal, dated May 30, 1564, Father Antônio Blasquez wrote that the natives were taken by a "fire in the heart", 
referring to the fevers that the virus caused in the patients, killing them in about two weeks, after spreading blisters and lesions in the face, hands, and feet. He described these blisters as "so disgusting and hideous that there was no one that could stand them or the stench that came out of them" (LEITE, 1931: p.406). Father Pedro da Costa, writing from Espirito Santo to the priests in Lisbon, in 1565, affirmed that "the blisters were so vile and of such great stench that they caused marvel, and many times they came loose from the putrefied flesh". (LEITE, 1931: p.456). The Jesuit described, in fact, the now well-known symptoms of smallpox, which start with fevers, muscle pains, and nausea, the indication of the infection of the airways; reaching the lymphatic system, the disease caused the blisters, starting in the mouth.

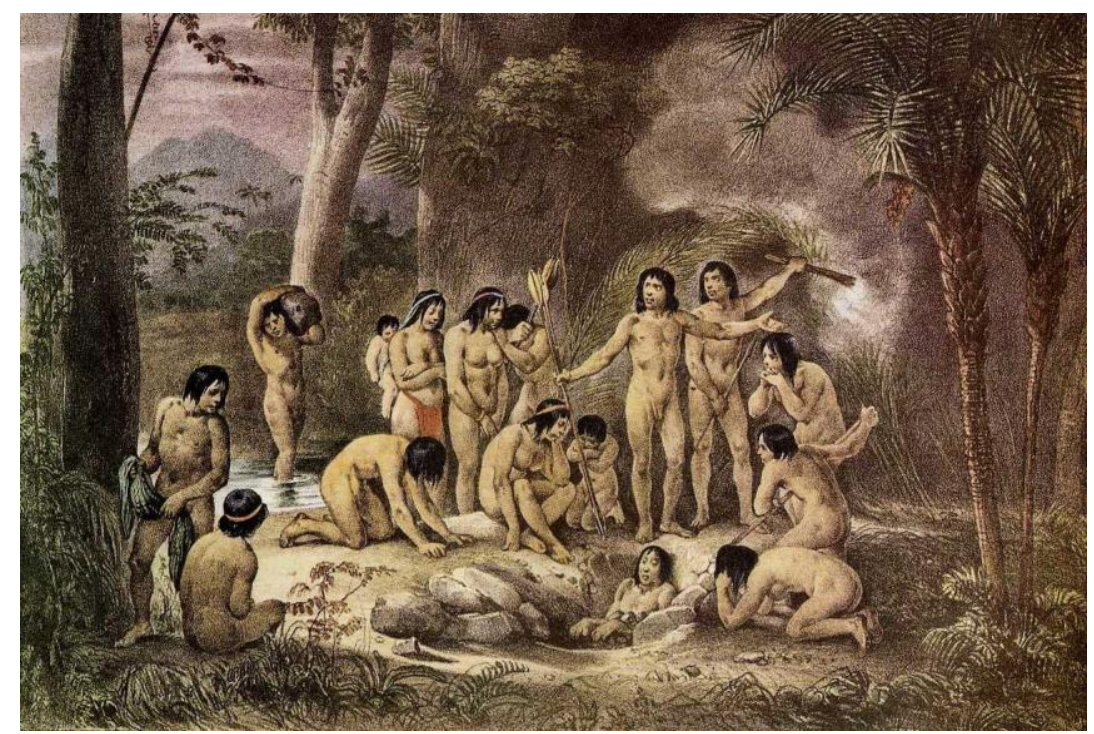

IMAGE 3 - Burial of a native. Litograph by Joahan Moritz Rugendas, Viagem pitoresca através do Brasil, 1835.

http://baraoemfoco.com.br/barao/portal/cultura/fotografia/Moritz-Rugendas/moritzrugendas-6.htm

The image above is merely an illustration of the burial of a native, probably a Tapuia, registered by the German artist J. Moritz Rugendas, in the $19^{\text {th }}$ century. It does not minimally give the real picture of what those infected with smallpox went through in the $16^{\text {th }}$ century. 
The image bellow is more realistic about the effects of the disease in the skin, especially regarding the blisters that spread all over the body of the infected.

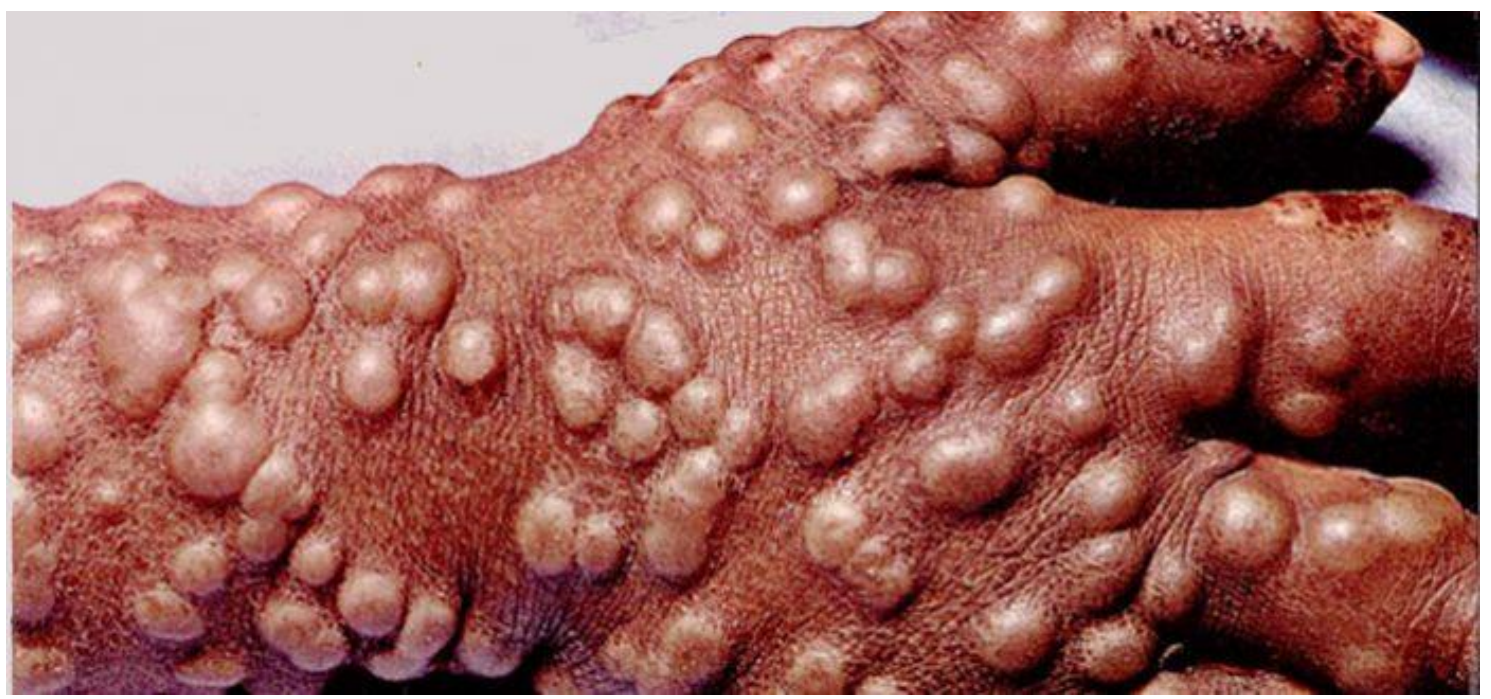

IMAGE 4 - Blisters in the hand of a late-stage patient infected with smallpox.

https://opas.org.br/tudo-sobre-variola-o-que-e-sintomas-tratamento-prevencao-e-mais/

The correspondence, on the other hand, registers the daily scenes of horror. The screaming of the sick, the piles of cadavers which, buried in shallow graves, were slowly eaten by pigs and other animals, the generalized fear. It also informs the Ignatian effort to care for the infected, through bloodletting, orange, or sugar, at first to try to cure them and, afterwards, to at least try to lessen the suffering of the dying. All for nothing. To this day, medical knowledge "does not recognize the official existence of any cure or therapeutical treatment capable of eliminating the virus, counselling therapeutical strategies that act on the symptoms, correcting the dehydration of the organism and the secondary infections caused by cutaneous eruptions and blisters" (ROQUE, 2004: p.184). ${ }^{3}$ At that time, as mentioned, there was no therapeutical strategy with a minimum of efficacy for the disease.

It was no coincidence that the Jesuit were those who gave a greater and better account of the plague of blisters in the $16^{\text {th }}$ century. Firstly, they wrote the most important reports of everyday colonization, better than those from chronicles or administrative sources; secondly, the plague found, in their villages, the perfect scenario 
to spread. Much more so than in the budding sugarcane plantations, which used, at most, a few dozen captive natives.

In his study on slavery and sugarcane economy in Bahia, Stuart Schwartz claimed that, in the years 1550 and 1560, there were almost no African slaves in sugarcane mills in Bahia, and circa two thousand on the mills of Pernambuco. In the mill São Pantaleão do Monteiro, in 1577, out of the forty slaves named in inventory, two-thirds were native, that is, around 26 . The mills in the coast only exceptionally reached a hundred slaves, African and Native, with a clear predominance of the natives until the end of the $16^{\text {th }}$ century. In the inventory records of the mill Sergipe do Conde, one of the biggest in Bahia, there were fifty-one Native slaves against only nine African slaves in 1572 - numbers that fell to, respectively, fifteen and seven in 1591, after the outbreaks of the blister plague (SCHWARTZ, 1988: p.68).

What I intend to point out, with these data, is not so much the predominance of Native slavery in the Baiano and Pernambucano mills up until the last decades of the 16th century, but the average number of captive natives in each mill, usually not passing the number of a few dozen. Besides the captive natives, due to the Jesuit action against slavery, there could also be an addition of native workers, many times falsely written down as slaves in the inventories, but this does not alter the modest number of natives grouped in colonial mills and plantations during the $16^{\text {th }}$ century.

In contrast, the villages of the Company of Jesus housed thousands of natives. During the decades 1550 and 1560, the Jesuit founded twelve villages, with the smaller of them - the village of Santo Antonio - having two thousand reduced natives. Between 1559 and 1583, five thousand natives were baptized there, with an estimated population of sixty thousand villagers in the twelve Ignatian missions (SCHWARTZ, 1988: p.48).

That being said, there is no doubt that the spread of smallpox happened in a much bigger scale in the villages than in the mills and plantations. A great paradox, the Ignatian policy of building coastal villages, thought of by the Provincial Manuel da Nobrega and put in motion during the years 1556-57, caused a grouping of natives that was fatal for that population. The foundation of villages near the centers of coastal population - loyal to the Jesuit ideal of saving the souls of the natives through catechesis and fighting their enslavement - was based in the conviction that, removed from the hinterlands and subject to a new discipline in a Christian environment, the 
natives would have an improved chance of salvation. Spiritual salvation, we must say, for the agglomeration of thousands of men, women, elders and natives in close space favored, rather, generalized death.

Many had barely arrived at the missions, after being led down from the hinterlands, and soon caught the plague, sometimes even before being baptized. Father Leonardo do Vale, in a letter written from Bahia to Father Gonçalo Vaz, in 1563, tells that the high mortality raised the prestige of the pajés-açus, who, in the Tupinambá tradition, had the gift of talking to the spirits of the ancestors, and even to incorporate them. The healers, called witches by the Ignatian, condemned the catechesis, starting from baptism, claiming that it was the cause of so many deaths. It is not surprising they said this, considering that thousands received in extremis baptism, in the terminal stage of the disease, dying right afterwards. The priests, on their turn, accused the native witches of being responsible for the disgrace, accusing them of promoting diabolical “carnalities and vices”, thus provoking "God's punishment” (LEITE, 1931: p.382-386).

The everyday life in the villages of the $16^{\text {th }}$ century was a dispute between rival religious groups, between priests and pajés, while the plague killed thousands of natives. Regardless of that, the chronology of the spread of smallpox in the $1500 \mathrm{~s}$ Brazilian coast matches the expansion of Jesuit villages. A coincidence of time and space, as the map bellow indicates. 


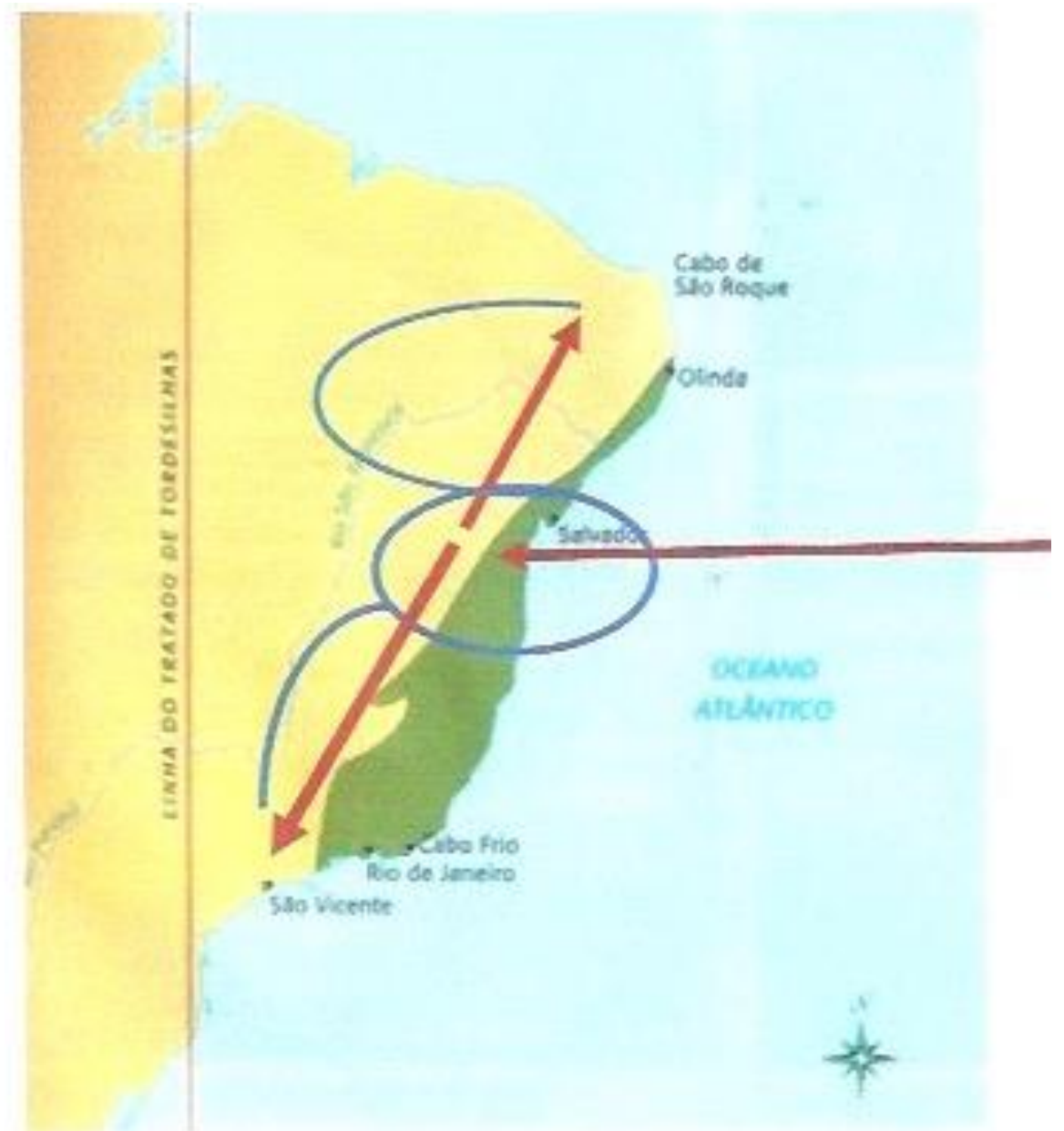

IMAGEM 5 - Smallpox and Catechesis in brazilian $16^{\text {th }}$ century coast Map designed by the author.

In red, we see the route of smallpox, coming from the Atlantic to Bahia, whether from Lisbon or from some African port involved with slave traffic, and from there it went North, towards Pernambuco, and South, towards São Vicente. In blue, we see the route of catechesis in the Ignatian villages, with the nucleus in Bahia and irradiating to the North and South Captaincies. The two processes are intertwined.

In the Brazilian case, we see the multiplication of the number of Native Brazilian, either slaves or villagers, that escaped from the coast into the hinterlands. This movement was documented by several accounts of different origins in the $16^{\text {th }}$ century. If, until the end of the 15th century, the Tupi populations had established themselves in the coast of South America through several routes, in the $16^{\text {th }}$ century the direction of migration inverted. The search for the Land Without Evil, a utopic horizon of the Tupi-Guarani tradition that encouraged the discovery of a mythical country, 
where the ancestors lived and the abundance of food was absolute, was redirected to the interior of the Brazilian land.

The Jesuits themselves, always alert, were the ones who registered most these migratory movements, prompted by the preaching of great pajés, even though lay chroniclers have also registered the process. But the Ignatians were the ones that started to call both the exhortative ceremonies and the movement resulting from them santidades. By pure chance, the Portuguese Inquisition produced a precious collection of documents about the main native santidade in 16th century Bahia, located in the forests of Recôncavo Baiano, in the decade of 1580. It was by chance, because the visitor from the Holy Office that arrived in Brazil, in 1591, came to persecute newChristians, blasphemers, and other deviants of official Catholicism and not to investigate Tupinambá ceremonies - that were, by the way, totally unknown to him (VAINFAS, 1995).

Maria Isaura Pereira de Queiróz was one of the ethnologists and anthropologists who - long before historians - registered that, in the 16th century, "native prophets went from village to village, presenting themselves as the reincarnation of tribal heroes, prompting the natives to abandon work and dance", for a new time would arrive "that would install on earth a kind of Golden Age”. (QUEIRÓZ, 1977: p.165). In fact, it was not exactly the arrival of a new time or space, but the return to traditional space and ancestrality. Mythic space and time, therefore, but porous, penetrated by history - never immutable - and, above all, by the smallpox affliction brought by colonization.

Unrestrained native Santidades, decimated native population. Some authors claim that what occurred to the native population in the beginning of the Iberic colonization of America, either Portuguese or Spanish, was an authentic genocide. Mortality was, without a doubt, absolutely catastrophic.

\section{The concept of genocide in a historical perspective}

There is no doubt the idea of genocide is to the point, when facing the demographic tragedy of the indigenous peoples of the Americas. However, in this case, is the concept of genocide inspired in the common-sense idea of murdering whole 
cultural and/or racial groups done by perverse and intolerant historical agents? Is there a historical or even institutional definition of genocide?

Before we get to that, we must say the concept of genocide only appeared in the $20^{\text {th }}$ century, proposed in 1942 by Raphael Lemkin, a Polish lawyer of Jewish origin. Lemkin referred to the Jewish Holocaust, perpetrated by Nazism, at that time still littleknown by the countries allied against Germany. He showed great vision, deducing that the German policy regarding the Jewish was, in fact, the extermination of all European Jews, cutting through the deceptive propaganda of the III Reich. Circa six million Jews were murdered, but the Nazi regime itself had calculated that approximately eleven million should be exterminated.

Lemkin defined genocide as a mass crime practiced against individuals of a certain nation or ethnic group, not because of any actions taken by them, but only because they belonged to a minority group hated by the perpetrating agent. The United Nations was inspired by Lemkin in 1946, when it defined genocide as "denying human groups the right to life", particularizing national, ethnical, racial or religious groups and reinforcing this definition in 1948, in the Universal Declaration of Human Rights.

Many years later, in 2017, British historian John Cox followed in the same lines, adding that "genocide differs from other mass crimes against humanity and other atrocities in its ambition. Genocide aims not to eliminate individual members of the target group, but destroy the group's capacity of social and cultural cohesion" (COX, 2017: p.17)

A variant on the concept of genocide was developed by the Cameroonian Achille Mbembe, in 2003, currently much mentioned in Humanities. Mbembe starts from the assumption that "the ultimate expression of sovereignty resides, to a large degree, in the power and the capacity to dictate who may live and who must die [...]. The State of exception and the relation of enmity became the normative basis of the 'right to kill', justifying the extermination of others" (MBEMBE, 2016: p.128) This is the concept of necropolitics. According to Mbembe, necropolitics depends of an intention of some State to exterminate minorities.

Thus, it would be impossible to demonstrate the Iberic Crowns formulated any project of extermination of the native populations. On the contrary, pressured by the 
Church, in special by the religious orders, they issued laws to protect the natives, freeing them from slavery in benefit of their spiritual salvation. Apart from religion, the Iberic Crowns, together with conquerors, colonizers, and ecclesiastics, intended to turn the natives, as far as possible, into the workforce that was essential for colonization. Thus, the concept of genocide does not fit, and neither does the concept of necropolitics.

However, considering the deaths of millions of Native Americans in the 16th century, could there be a problem with the concept? I believe historians must anchor themselves in concepts to narrate and explain History; but, if they become captive of theories and concepts, it might occur that reality becomes hidden. The smallpox plague in the 16th century was not intentionally carried out by the Iberic Crowns, but would not have occurred without the contact the Spanish and the Portuguese had with the native populations, as a prelude to Iberic colonization.

I am not certain that one can affirm that there was genocide, either from the conceptual or institutional point of view. Thinking, however, about the demographic tragedy caused by European colonialism, genocide makes a good cause. The conclusion for this article is an advice to historians: do not be enslaved to often misleading concepts of Humanities; rather, side with both quantitative and qualitative factual reality. The tragedy of the indigenous populations of the Americas, caused by smallpox was, in fact, the most devastating pandemic of Universal History.

\section{References}

ARIÈS, Philippe. História da morte no Ocidente. Rio de Janeiro: Francisco Alves, 1977.

AULDRIN, Dauril \& MILLER, Joseph. Unwanted cargoes: the origins and dissemination of Smallpox via slave trade from Africa to Brazil. In: KIPLE, K. F. The African exchange. Durham: Duke University Press, 1988, p.34-109

CALAINHO, Daniela. Metrópole das mandingas. Religiosidade negra e Inquisição Portuguesa no Antigo Regime. Rio de Janeiro: Garamond, 2008. 
CARDOSO, Ciro. Sobre os modos de produção coloniais na América. In: SANTIAGO, Théo. América colonial. Rio de janeiro: Pallas, 1975, p. 61-68.

CLARK, Stuart. French Historians and Early Modern Popular Culture. Past \& Present, 6:, 1983, 62-99.

COX, John. To Kill a People: Genocide in the Twentieth Century, 2a. ed. New York: Oxford University Press, 2017.

DARMON, Pierre. A cruzada antivariólica. In: LE GOFF, J. et al. (orgs). As doenças têm história. Lisboa: Terramar, 1985, p.305-321.

DELORT, Robert. Que a peste seja o rato. In: LE GOFF, J. et al. (orgs). As doenças têm história. Lisboa: Terramar, 1985, p.109-126.

DELUMEAU, Jean. História do medo no Ocidente. São Paulo: Companhia das Letras, 1989.

LE GOFF, Jacques et al. (orgs). As doenças têm história. Lisboa: Terramar, 1985.

LEITE, Serafim (org.). Cartas avulsas (1550-1568). Rio de Janeiro: Academia Brasileira de Letras, 1931.

FREYRE, Gilberto. Casa Grande \& Senzala (1933). 16a . ed. Rio de Janeiro: José Olympio, 1973.

MAESTRI, Mário. Os senhores do litoral. Conquista portuguesa e agonia tupinambá no litoral brasileiro. Porto alegre: EDUFRS, 1995.

MARCHANT, Alexander. Do escambo à escravidão. São Paulo: Companhia Editora Nacional, 1980.

NEVES, Luís F. Baeta. O combate dos soldados de Cristo na Terra dos Papagaios. Rio de Janeiro: Forense Universitária, 1980.

NOVAIS, Fernando. Portugal e Brasil na crise do antigo Sistema Colonial. São Paulo: HUCITEC, 1979.

MBEMBE, Achille. Necropolítica. Artes e ensaios 32, 2016, p.123-151

QUEIRÓZ, Maria Isaura. O messianismo no Brasil e no mundo. $2^{\mathrm{a}}$. Ed. São Paulo: Alfa-Ômega, 1977. 
ROQUE, RICARDO. Sementes contra a varíola: Joaquim Vás e a tradução científica das pevides de bananeira brava em Goa, Índia (1894-1930). História, Ciências, Saúde-Manguinhos 11, 2004 p.183-222,

SANCHEZ-ALBORNOZ. La población de América Latina. Madrid: Alianza Editorial, 1973, p.72.

SCHWARTZ, Stuart. Segredos internos. Engenhos e escravos na sociedade colonial. São Paulo: Companhia das Letras, 1988.

SILVA, Alberto da costa e. A manilha e o libambo. África e a escravidão. Rio de Janeiro: Nova Fronteira, 2002.

SILVA, António de Moraes. Dicionário da Língua portuguesa. 2a . Ed. Lisboa: Typografia Lacérdina, 1813.

VAINFAS, Ronaldo. A heresia dos índios. Catolicismo e rebeldia no Brasil colonial. São Paulo: Companhia das Letras 1995.

WACHTEL, Nathan. Los vencidos. Los indios del Perú frente a la conquista española. México, Fondo de Cultura, 1976.

\section{Notes}

1 - The present article is the result of a conference given at the Seminário Virtual Internacional de História Moderna (International Virtual Seminary of Modern History). I am grateful to CNPq and to FAPERJ for the funding of my research.

2 - Traanslation of the title by the author: Cargas indesejáveis: origens e disseminação da variola através do tráfico de escravos da África para o Brasil.

3 - Jenner observed that women who milked cows and caught the so-called Cowpox, became immune to Smallpox. Jenner inoculated the pus from the wound of a milking-woman contaminated with Cowpox in an eight-year-old boy infected with smallpox, and was able to save him from the virus. Revolta da Vacina (Rebellion Against the Vaccine), occurred in Rio de Janeiro, in the year 1904, as a reaction to the mandatory vaccination campaign led by the Brazilian sanitarist Oswaldo Cruz. 